\begin{tabular}{|l|l|l||}
\hline \multicolumn{2}{|c|}{ PublisherInfo } \\
\hline \hline PublisherName & $:$ & BioMed Central \\
\hline \hline PublisherLocation & $:$ & London \\
\hline \hline PublisherImprintName & $:$ & BioMed Central \\
\hline \hline
\end{tabular}

\title{
Making ant wings
}

\begin{tabular}{|l|c|l||}
\hline \multicolumn{2}{|c|}{ ArticleInfo } \\
\hline \hline ArticleID & $:$ & 4530 \\
\hline \hline ArticleDOI & $:$ & $10.1186 /$ gb-spotlight-20020716-01 \\
\hline \hline ArticleCitationID & $:$ & spotlight-20020716-01 \\
\hline \hline ArticleSequenceNumber & $:$ & 196 \\
\hline \hline ArticleCategory & $:$ & Research news \\
\hline ArticleFirstPage & $:$ & 1 \\
\hline \hline ArticleLastPage & $:$ & 2 \\
\hline \hline & & RegistrationDate : 2002-7-16 \\
\hline ArticleHistory & $:$ & OnlineDate \\
\hline \hline ArticleCopyright & $:$ & BioMed Central Ltd2002-7-16 \\
\hline \hline ArticleGrants & $:$ & \\
\hline \hline ArticleContext & $:$ & 130593311 \\
\hline \hline
\end{tabular}




\section{Jonathan B Weitzman}

Email: jonathanweitzman@hotmail.com

The ant genome can direct the formation of queens with fully functional wings or wingless soldiers and workers - a phenomenon known as wing polyphenism. In the July 12 Science, Ehab Abouheif and Gregory Wray define the genetic network underlying wing development in ant castes (Science 2002, 297:249-252). They examined genes orthologous to those involved in wing-patterning networks in other organisms. Abouheif and Wray analyzed the expression patterns of six conserved genes that have been characterized in wing development in Drosophilaand butterflies. They found some differences in expression patterns between winged queens and wingless soldiers or workers, and differences in gene expression between closely related ant species. This gene network is found to be highly conserved but evolutionarily labile, explaining its important contribution to successful ant evolution.

\section{References}

1. Science, [http://www.sciencemag.org]

2. Pattern formation and eyespot determination in butterfly wings. 